\title{
Turks, Moors and Englishmen in the Age of Discovery
}

Nabil Matar. New York: Columbia University Press, 1999. 268 pages.

Nabil Matar's Turks, Moors and Englishmen in the Age of Discovery is a welcome addition to the important yet often-overlooked scholarship of cross-cultural exchanges between Muslims and non-Muslims in the era between the Crusades and modern European colonial hegemony. Drawing on literary and historical sources from the Elizabethan and Stuart periods, Matar strikes at the heart of the Orientalism debate with a complicated yet plausible link between English representations of Muslims and native Americans and later imperialist racism. By stressing a triangular power relationship between England, North Africa and the Ottoman world, and the new American colonies, Matar convincingly argues that it was the very failure of the English to conquer the Muslims in the face of English successes in America against the indigenous populations that led Britons to transfer their ideas about "savage natives" from the American Indians to the Muslims. According to Matar, it was this transference that laid the foundation for centuries of racism and stereotyping against Islam and its adherents in western scholarship and popular culture. By using the language of racism created during their destruction of the native Americans against the Muslims they could not destroy, the English in the Age of Discovery created the ideological foundation for their conquests in the Age of Imperialism.

In his introduction, Matar is quick to remind his readers that Muslims were the most familiar and significant Others in Elizabethan and Stuart England; unlike Americans, they were not in the colonial sights of the English, but rather, to be admired and feared. Indeed, it was their very resistance to being conquered that led to their demonization in literary and theological works. However, in the realm of politics, English rulers were keen to forge political and economic ties with Muslim governments, because they knew they needed such ties to maintain their own national and economic security. Matar is also careful to point out that English representations of Muslims cannot be taken at face value as accurate historical sources describing lived experiences of Muslims, but rather, as representations of how the English viewed the Islamic world they knew vis-a-vis the other major group of non-Christians with which they were actively engaged, Native Americans.

The bulk of Matar's work can be divided into two parts. Chapter One 
("Turks and Moors in England"), Chapter Two ("Soldiers, Pirates, Traders, and Captives: Britons Among the Muslims"), and Chapter Three ("The Renaissance Triangle: Britons, Muslims, and American Indians") focus on specific venues in which Britons and Muslims encountered one another, while Chapter Four ("Sodomy and Conquest") and Chapter Five ("Holy Land, Holy War") present particular thematic cases explored in English literature regarding Islamic society. The first half of the book gives a good historical overview of the variety of situations in which cross-cultural encounters could and did emerge. Muslims made themselves present in England in a variety of venues and circumstances, including trade, diplomacy, and as slaves and servants, and their ubiquitous presence in English literary works of the day demonstrates the impact they had on the English imagination. But, although they were (according to Matar) the most prominent non-Christian group in the country, there were far more encounters between Muslims and Englishmen outside of Britain than within. Indeed, the vast majority of representations utilized by Matar were generated by Britons keenly aware of their subservient position to the Muslims, as they were written in the contexts of captivity, mercenary military service, or trade outside the boundaries of English law. Such relationships were coupled with legitimate economic and diplomatic exchanges in the Muslim world, yet for Matar, it is captivity accounts in particular that are the most useful, because "the captivity accounts are the first realistic documents in English that are situated within the conflict between Christendom and Islam." These and other documents from encounters outside of Britain reveal a reflexive relationship whereby the Muslims gained technical knowledge from the English and the English garnered military footholds within Muslim administrations.

However, the knowledge gained by the English in the context of captivity also paved the way for the collection of colonial knowledge to be used in other venues. Realizing their inability to conquer the Ottomans or the Moroccans, English traders and government officials turned their attentions toward the New World and its potential for colonial exploitation. Chapter Three serves as a transition for Matar, enabling him to introduce his main argument, that experiences with American Indians in the New World provided Britons with a ideological framework for coming to terms with their inferiority against the Muslim world they knew much better. Although there were far more English people in the Muslim Mediterranean than the American colonies in the Age of Discovery, Matar asserts that it was the very success against the Native Americans--in large part due to 
disease as much as strategy--which allowed the English to superimpose their superiority over the world they knew much better--that of the Muslims.

This was most effectively done, according to Matar, through the literary exploitation of two key theological themes: sodomy and the ideals of "holy war." Both native Americans and Muslims were increasingly portrayed as frequently and willingly engaging in homosexual activities reminiscent of those that were assumed to bring on God's destruction of the Biblical city of Sodom. For many Britons, this legitimated the conquest of the Americans, who were viewed as lazy and unwilling "properly" to utilize the lands they "inhabited" (rather than lands they "owned") due to their moral failings. Thus, their land should be conquered by those who could serve as better custodians. This was heightened by the second common theme, that of the New World serving as a Holy Land in wait for a New Jerusalem established by English colonists. This ideal arose just as the notions of Holy War to conquer Palestine--the "original" Holy Land--were fading in Europe. The Ottoman Porte was portrayed as a morally and sexually corrupt body undeserving of custodianship for Palestine, but conquest was far beyond the abilities of the English. Thus, they conflated Palestine and the Americas, as well as their inhabitants: Palestinians and Americans alike were viewed as sodomites who should be cast out of their "empty" lands, but in only one venue was that a feasible reality for the British in the Age of Discovery.

In his conclusion, "Britons, Muslims, and the Shadow of the American Indians," Matar looks toward the eighteenth century and the beginnings of significant British imperialist threat to the Middle East. The links made between Muslims and American Indians in the Age of Discovery were enhanced as the English gained more prominence in their imperialist endeavors throughout the world, establishing the foundation of colonial knowledge collection that ultimately resulted in the Orientalist pursuit. By knowing--or at least representing themselves as knowing--the Muslim world through centuries of encounters, coupled with their conflation of non-Christians they subdued with those they wished to conquer, the English were on the way to becoming the preeminent imperialist power of the Age of Imperialism. In this way, Matar's book serves as a dramatic and important contribution to the Orientalist debate, for it provides an historicized literary review of many English accounts of the Ottoman and North African worlds at a time in which English hegemony was far from predictable, and the Muslim world served as a powerful symbol of what the 
English wished they could achieve themselves.

Concise (194 pages of text) yet well documented (34 pages of notes, 24 pages of bibliography), Matar supplements his fascinating analysis with three useful appendixes. Appendix A is a bibliography of English captivity accounts dating from 1577 until 1704. Appendix B is Matar's summary of "The Journey of the First Levantine to America," the travelogue of a Syriac Catholic priest who wrote the first Arabic rihla describing the New World (1668-1683). The rihla is a very promising work, and I hope that Matar will do more with it in the future; however, perhaps because it was written by a Christian, it demonstrates that this Arab priest had already assimilated the negative notions of native Americans propagated by Europeans, and his account reveals someone who sees what he expected to see before his arrival, as the European accounts do. Matar views this result as one of the most damaging effects of colonialism, racism propagated by the imperialist at the expense of the victims of imperialism. The rihla could also be more fully explored by illuminating the diversity of the world of the Levant and questions about the impact of non-Muslim churches and governments in the Ottoman context before the Eastern Question became a prominent feature of global politics. Finally, Appendix C is a translation of Ahmad Bin Qasim al-Hajari al-Andalusi on the question of sodomy and Islam, set against a conversation between a Muslim and a Christian on the subject. This is an interesting inclusion, but because Matar gives no commentary, it needs more context to be fully integrated into his otherwise interesting study.

Overall, Nabil Matar has given scholars of Orientalism and its effects a very interesting and important book. This is not a book about the world of Islam in the Age of Discovery, but rather, a book about the way Islam was perceived by those outside its membership--but well within its influence. By examining the ways that cross-cultural exchanges between the successful Muslim imperialists of the Age of Discovery and the soon-to-be successful English imperialists of the Age of Imperialism shaped the conquest of the Americas, as well as the foundation of modern racism against Muslims in the Middle East, Matar has written an excellent example for historians and literary critics alike who wish to understand how representations made empire attractive and/or odious to future generations.

Nancy L. Stockdale

Department of History University of Central Florida 